\title{
What's on YouTube? A Case Study on Food and Beverage Advertising in Videos Targeted at Children on Social Media
}

\author{
LeeAnn Tan, MB BCh BAO,' See Hoe Ng, MSc, \\ Azahadi Omar, MD, MPH,' and Tilakavati Karupaiah, PhD, APD, AN ${ }^{3}$
}

\section{Abstract}

Background: Unhealthy food marketing to children is a key risk factor for childhood obesity. Online video platforms have surpassed television as the primary choice for screen viewing among children but the extent of food marketing through such media is relatively unknown. We aimed to examine food and beverage advertisements (ads) encountered in YouTube videos targeting children in Malaysia.

Methods: The social media analytics site SocialBlade.com was used to identify the most popular YouTube videos $(n=250)$ targeting children. Ads encountered while viewing these videos were recorded and analyzed for type of product promoted and ad format (video vs. overlay). Food and beverage ads were further coded based on food category and persuasive marketing techniques used.

Results: In total 187 ads were encountered in sampled videos. Food and beverage ads were the most common at $38 \%(n=71)$, among which $56.3 \%(n=40)$ promoted noncore foods. Ads for noncore foods were more commonly delivered as video rather than overlay ads. Among ads promoting noncore foods, the most commonly employed persuasive marketing techniques found were taste appeal (42.3\%), uniqueness/novelty (32.4\%), the use of animation (22.5\%), fun appeal $(22.5 \%)$, use of promotional characters $(15.5 \%)$, price $(12.7 \%)$, and health and nutrition benefits $(8.5 \%)$.

Conclusions: Similar to television, unhealthy food ads predominate in content aimed toward children on YouTube. Policies regulating food marketing to children need to be extended to cover online content in line with a rapidly-evolving digital media environment. Service providers of social media can play a part in limiting unhealthy food advertising to children.

Keywords: advertising; children; food marketing; obesity; social media; YouTube

\section{Introduction}

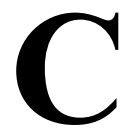
hildhood obesity is a crucial public health problem that has seen a dramatic rise in worldwide prevalence over the past three decades. ${ }^{1-3}$ About two-thirds of obese children eventually become obese adults, ${ }^{4}$ carrying with them an increased risk of chronic disease in later life. ${ }^{5-8}$ Obesity prevention efforts aimed at children are therefore considered a high priority, with the potential for massive savings in future healthcare expenditure. ${ }^{9}$ An important environmental factor (amongst other genetic, behavioral, and dietary components) contributory to the multifactorial problem of childhood obesity ${ }^{10}$ is the exposure of children to food and beverage advertising on television and other media, which has been shown to influence children's food preferences, purchases, and consumption. ${ }^{11,12}$ The regulation and restriction of food marketing to children, therefore, is a highly promising avenue for intervention. ${ }^{13}$

The bulk of existing research examining food marketing targeted at children has focused on traditional media, specifically television advertising - the extent and nature of which has been investigated extensively in many countries $^{14-28}$ - with overwhelming evidence that unhealthy foods tend to be promoted most and multiple persuasive marketing techniques are often implemented. ${ }^{12,29}$ In comparison, only a few studies explored food marketing to

\footnotetext{
'Institute for Public Health, Ministry of Health Malaysia, Kuala Lumpur, Malaysia.

${ }^{2}$ Faculty of Social Sciences, University of Wollongong, Wollongong, Australia.

${ }^{3}$ Faculty of Health and Medical Sciences, Taylor's University, Subang Jaya, Malaysia.
}

(C) LeeAnn Tan et al., 2018; Published by Mary Ann Liebert, Inc. This Open Access article is distributed under the terms of the Creative Commons Attribution Noncommercial License (http://creativecommons.org/licenses/by-nc/4.0/) which permits any noncommercial use, distribution, and reproduction in any medium, provided the original author(s) and the source are credited. 
children in new media (mainly on children's and food brand websites)..$^{30-34}$ This is despite industry data showing diminishing marketing expenditure for traditional media (television, print, and radio), ${ }^{35}$ whereas digital or new media marketing expenditure saw a three-digit percentage growth from 2005 to $2009 .{ }^{36}$

The "digital age" alone has also seen a shift from "traditional" websites-usually accessed by typing an address into a web browser or clicking a specific linktoward integrated social media platforms that are accessible across the entire gamut of devices from desktop computers to mobile phones, tablets, and even smart watches. It was recently observed that television is no longer the primary choice for screen viewing among children, ${ }^{37,38}$ having been surpassed by online viewing platforms, among which YouTube is dominant with over 1 billion unique users monthly. ${ }^{39}$ Since its inception only a little over a dozen years ago, YouTube has become a dominant source of media consumption among children in many developed countries as shown by a contemporary survey in the United Kingdom, where half of children aged 3-4 and more than eight in ten aged 5-15 use YouTube. ${ }^{40}$

Watching videos online is now normative behavior among toddlers ${ }^{37}$ and parents frequently make use of touchscreens as "digital pacifiers" or "shut-up toys" to keep children occupied and calm them down in public places. ${ }^{41-43}$ In view of the rapidly rising popularity of this social media platform among children, we undertook a case study to examine food and beverage advertisements (ads) encountered in YouTube videos targeting Malaysian children.

\section{Methods}

The flow of data collection for this study is summarized in Figure 1.

\section{Sampling of Videos}

YouTube categorizes its videos into several main categories such as "Auto \& Vehicles," "Education," "Entertainment," "How-To \& Style," "Music," "Travel," and so on. However, a "Children" or "Kids" category was noticeably absent. In view of this, nonproprietary data were obtained from SocialBlade.com, a social media analytics website independent of YouTube, which tracks and collects detailed statistics on YouTube channels such as number of views or followers. The top 25 most popular child-centric YouTube channels (Appendix 1) were identified using the "Kids" tag as a filter and ranked by total lifetime views on SocialBlade.com. This list is publicly available on https:// socialblade.com/youtube/top/tag/kids/videoviews, although the rankings are of course subject to change over time.

The top 10 most-viewed videos for each of the 25 channels were then selected to be included in the sample $(n=250)$. This was done by loading a list of all videos uploaded by a particular channel, and then using the inbuilt "Sort" button to rank the videos by number of views. At the time of recording, the lifetime view counts of all videos totaled 46.8 billion views.

\section{Recording}

All shortlisted videos were viewed on the YouTube website (www.youtube.com) using the Google Chrome browser

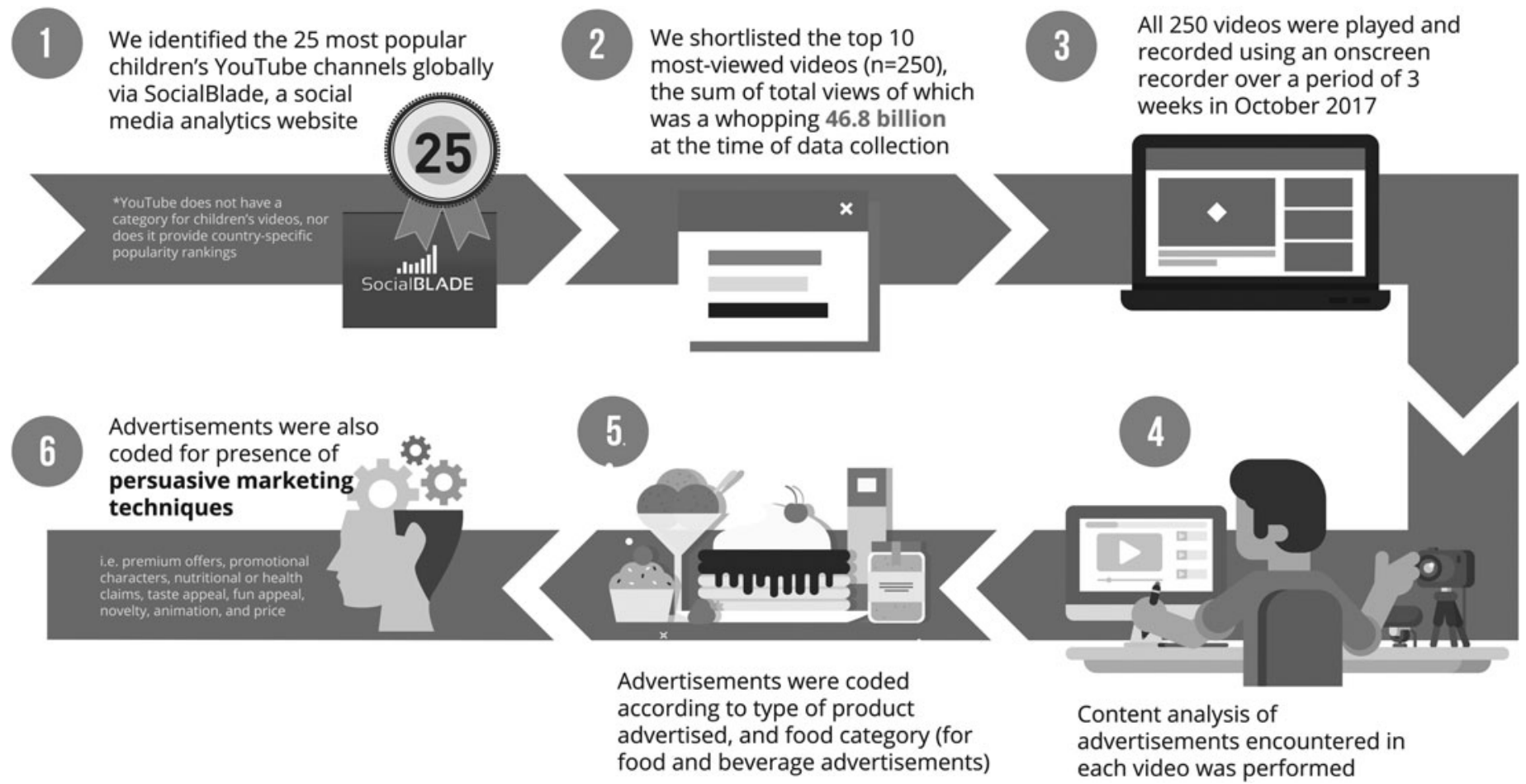

Figure 1. Flow of data collection for this study. 
(Google, Inc., California, USA). To circumvent the use of cookies (small files stored on a web browser that tracks and records users' activities and browsing habits) and prevent targeted advertising, the browser was set to "incognito" mode, and a new window was opened each time a video was viewed. ${ }^{44}$ While the videos and ads played within the browser they were recorded with Apowersoft Screen Recorder Pro (Apowersoft Ltd., Hong Kong). All videos were recorded over a period of 3 weeks in October 2017, totaling 54 hours and 35 minutes. Recording was conducted in Kuala Lumpur, Malaysia, which was the site for this study.

\section{YouTube Ad Formats}

At the time of recording, YouTube has two main types of in-video ad formats: (a) video ads that are either skippable or nonskippable, and (b) semi-transparent overlay ads that appear on the lower $20 \%$ portion of the video-both of which were included in our sample. ${ }^{45}$ Both video and overlay ads can appear at any point in a video, although video ads commonly appear at the beginning. Overlay ads are generally either text-only, static images, or have very little movement and animation to them. They are also less expensive to place than other ad formats. ${ }^{46}$

Provided they meet certain "video monetization criteria," the video owner can choose whether or not to have ads present in their videos, and their format and frequency (but not content or advertiser); for this they will receive monetary payouts accordingly. YouTube also displays ads elsewhere on the desktop version of the site (usually to the right of the video player, above the videos suggestion list), however, these were excluded from the present study as they are not located within the boundaries of the video player (i.e., not in-video ads).

\section{Data Coding and Analysis}

All ads encountered were categorized based on the type of product advertised. Food and beverage ads were coded according to a standard list of 36 food codes ${ }^{14}$ (Appendix 2), with modifications made for better relevance to the Malaysian food supply as per a previous study focusing on television ads. ${ }^{47}$ Each food code was further assigned to one of three food categories (core, noncore, and miscellaneous foods). Core foods are nutrient dense and low in discretionary energy and can be recommended to be consumed daily, while noncore foods are high in undesirable nutrients such as high fat, refined sugars, and salt. ${ }^{14}$ However, since the number of ads promoting core foods was very low $(n=2)$, they were analyzed in combination with the miscellaneous foods category.

The content of food and beverage ads were further analyzed to determine prevalence of the most frequently reported persuasive marketing techniques found to promote food to children on television, as identified by a published systematic review on the subject. ${ }^{29,48}$ Two researchers (L.T. and S.H.N.) simultaneously performed the coding. Interrater reliability was calculated based on the method used by Zuppa et al. $^{49}$ and recorded as $94 \%$ for food category assignment and $100 \%$ for identification of persuasive marketing techniques. Disagreement on food category was resolved by discussion with a senior investigator (T.K.) until a consensus was reached. Chi-square testing was used to compare ad formats used to promote noncore foods and core and miscellaneous foods.

\section{Results}

A total of 187 ads were encountered while viewing videos in the sample, of which 108 were overlay ads, 74 were skippable video ads, and 5 were nonskippable video ads. Shortlisted videos that did not show any ads were nonetheless included for analysis, to ensure a fair representation of the frequency of food and beverage ads found within the 250 most popular children's videos. Although content analysis of the videos is beyond the scope of this article, both coders agreed that all videos viewed were unquestionably child-centric (mostly toy unboxing videos, nursery rhymes, and children's songs), and were unlikely to be voluntarily watched by the average teen or adult viewer.

Twelve product types were promoted in ads encountered. Food and beverage ads were most common $(n=71$, $38 \%)$, followed by financial services $(n=33,17.6 \%)$ and technology/web services $(n=22,11.8 \%)$. On average we encountered 1.3 ads promoting food and beverage products for every hour of videos viewed (Table 1).

Among the food and beverage ads, there were more ads for noncore foods $(n=40,56.3 \%)$ than both core and miscellaneous foods combined $(n=31,43.7 \%)$. The most common food type advertised, however, was vitamin/mineral or other dietary supplements $(n=20,28.2 \%)$ - belonging to the miscellaneous food category, followed by fast food $(n=15$, $21.1 \%)$ and chocolate and candy $(n=12,16.9 \%)$ - both of which fall under the noncore food category.

Ads for noncore foods were much more commonly delivered as video rather than overlay ads $(82.5 \%$ vs. $17.5 \%)$. The number of noncore foods promoted via video ads was also significantly higher (Table 2 ) compared to core and miscellaneous foods $\left(\chi^{2}=37.05, p<0.0001\right)$. Among ads promoting noncore foods, the most commonly employed persuasive marketing techniques (Table $3^{50}$ ) found were taste appeal (42.3\%), marketing a product as being unique or new $(32.4 \%)$, the use of animation (22.5\%), fun appeal $(22.5 \%)$, use of promotional characters $(15.5 \%)$, price $(12.7 \%)$, and health and nutrition benefits $(8.5 \%)$.

\section{Discussion}

To our knowledge, this is the first case study to examine food and beverage advertising encountered in YouTube videos targeted at children. In a recent report the World Health Organization Europe ${ }^{51}$ expressed concern regarding the marketing of unhealthy foods in digital and social media, which not only amplifies advertising in traditional media but is also very poorly regulated and monitored. Generally, the inherent networking nature and literate environment of popular social media sites such as Facebook, 


\section{Table I. Product Types and Food Categories}

\begin{tabular}{|c|c|c|}
\hline Category & $\begin{array}{l}\text { Frequency } \\
\text { (\%) }\end{array}$ & $\begin{array}{c}\text { Rate } \\
\text { (ads/h) }\end{array}$ \\
\hline \multicolumn{3}{|l|}{ Product type $(n=187)$} \\
\hline Food and beverage & $71(38.0)$ & 1.30 \\
\hline Financial services & $33(17.6)$ & 0.60 \\
\hline Technology/web services & $22(11.8)$ & 0.40 \\
\hline Entertainment and travel & $16(8.6)$ & 0.29 \\
\hline Household appliances & $15(8.0)$ & 0.27 \\
\hline Health and medicinal & II (5.9) & 0.20 \\
\hline Clothing & $5(2.7)$ & 0.09 \\
\hline Education & $4(2.1)$ & 0.07 \\
\hline Toys & $4(2.1)$ & 0.07 \\
\hline Baby products & $3(1.6)$ & 0.05 \\
\hline Property & $2(1.1)$ & 0.04 \\
\hline Cleaning products & I (0.5) & 0.02 \\
\hline \multicolumn{3}{|l|}{ Food and beverage $(n=7 I)$} \\
\hline Noncore foods ${ }^{a}$ & $40(56.3)$ & 0.73 \\
\hline $\begin{array}{l}\text { Fast food (not only healthier } \\
\text { options advertised) }\end{array}$ & $15(21.1)$ & 0.27 \\
\hline Chocolate and candy & $12(16.9)$ & 0.22 \\
\hline $\begin{array}{l}\text { Sweet breads/cakes/muffins/buns, } \\
\text { sweet glutinous rice balls/cakes, high } \\
\text { fat savory biscuits, pies, and pastries, } \\
\text { sweet sticky rice/rice pudding }\end{array}$ & $6(8.5)$ & 0.11 \\
\hline $\begin{array}{l}\text { Flavored or dairy products with } \\
\text { added sugar and alternatives }\end{array}$ & $3(4.2)$ & 0.05 \\
\hline $\begin{array}{l}\text { Ice cream, iced confection, and } \\
\text { desserts }\end{array}$ & $3(4.2)$ & 0.05 \\
\hline Sugar sweetened drinks & I (I.4) & 0.02 \\
\hline Core $^{b}$ and Miscellaneous ${ }^{c}$ foods & $31(43.7)$ & 0.57 \\
\hline $\begin{array}{l}\text { Low sugar and high fiber } \\
\text { breakfast cereals }(<20 \mathrm{~g} \text { sugar } / 100 \mathrm{~g} \\
\text { and }>5 \mathrm{~g} \text { dietary fiber } / 100 \mathrm{~g})\end{array}$ & I (I.4) & 0.02 \\
\hline $\begin{array}{l}\text { Fruits and fruit products without } \\
\text { added fats, sugars, or salt }\end{array}$ & I (I.4) & 0.02 \\
\hline $\begin{array}{l}\text { Vitamin/mineral or other } \\
\text { dietary supplements }\end{array}$ & $20(28.2)$ & 0.37 \\
\hline Baby and toddler milk formulae & $9(12.7)$ & 0.16 \\
\hline
\end{tabular}

Food and beverage categories with no ads were excluded from the table. See Appendix 2 for the full list.

${ }^{a}$ Food that is relatively high in undesirable nutrients such as high fat, refined sugars, and salt.

${ }^{b}$ Food that is recommended to be consumed daily to meet nutrient requirements.

'Food that is added to flavor meals (e.g., recipe additions); supplements; milk formula for baby and toddlers; tea and coffee (plain); fast food (with no noncore foods); or local restaurant and supermarkets.

\begin{tabular}{|c|c|c|}
\hline Category & $\begin{array}{l}\text { Video } \\
\text { ads (\%) }\end{array}$ & $\begin{array}{l}\text { Overlay } \\
\text { ads (\%) }\end{array}$ \\
\hline \multicolumn{3}{|l|}{ Food and beverage $(n=7 I)$} \\
\hline Noncore foods & $33(82.5)$ & $7(17.5)$ \\
\hline $\begin{array}{l}\text { Fast food (not only healthier options } \\
\text { advertised) }\end{array}$ & $8(53.3)$ & $7(46.7)$ \\
\hline Chocolate and candy & $12(100)$ & $0(0.0)$ \\
\hline $\begin{array}{l}\text { Sweet breads/cakes/muffins/buns, } \\
\text { sweet glutinous rice balls/cakes, high } \\
\text { fat savory biscuits, pies, and pastries, } \\
\text { sweet sticky rice/rice pudding }\end{array}$ & $6(100)$ & $0(0.0)$ \\
\hline $\begin{array}{l}\text { Flavored or dairy products with } \\
\text { added sugar and alternatives }\end{array}$ & $3(100)$ & $0(0.0)$ \\
\hline $\begin{array}{l}\text { Ice cream, iced confection, and } \\
\text { desserts }\end{array}$ & $3(100)$ & $0(0.0)$ \\
\hline Sugar sweetened drinks & $I(100)$ & $0(0.0)$ \\
\hline Core and Miscellaneous foods & $3(9.7)$ & $28(90.3)$ \\
\hline $\begin{array}{l}\text { Low sugar and high fiber breakfast } \\
\text { cereals }(<20 \mathrm{~g} \text { sugar } / 100 \mathrm{~g} \text { and }>5 \mathrm{~g} \\
\text { dietary fiber } / 100 \mathrm{~g})\end{array}$ & $0(0.0)$ & I $(100)$ \\
\hline $\begin{array}{l}\text { Fruits and fruit products without } \\
\text { added fats, sugars, or salt }\end{array}$ & I (100) & $0(0.0)$ \\
\hline $\begin{array}{l}\text { Vitamin/mineral or other dietary } \\
\text { supplements }\end{array}$ & $0(0.0)$ & $20(100.0)$ \\
\hline Baby and toddler milk formulae & $2(22.2)$ & $7(77.8)$ \\
\hline
\end{tabular}

Twitter, Tumblr, and Instagram effectively precludes very young children. YouTube, however, is an obvious exception in this group with its largely visual content and simple user interface that facilitates easy and immediate access for infants and preschoolers who do not need to open a web browser to find their favorite sites. ${ }^{41,52}$ Therefore, the predominance of unhealthy food marketing on YouTube as found in this study is particularly worrying considering the affinity of very young children toward the platform, as they are least adept at recognizing persuasive intent when exposed to advertising and hence the most vulnerable group to marketing techniques or brand imprinting. ${ }^{53,54}$

We found that similar to television, ads for unhealthy foods predominate among the top child-centric YouTube videos, which have collectively been viewed 46.8 billion times around the world. The rate of noncore food advertising on YouTube in this case study was found to be lower than that of television ( 0.73 vs. $2.73^{47}$ ads per hour) in Malaysia and other countries in the Asia Pacific region. ${ }^{15}$ Despite this, we argue that YouTube may prove to be a much more potent marketing medium than television for several reasons.

Unlike on broadcast television where there are specific timeslots for children's programs, videos on YouTube are easily accessible and available at any time. The platform 


\section{Table 3. Persuasive Marketing Techniques}

\begin{tabular}{|c|c|c|c|c|c|}
\hline \multirow{2}{*}{$\begin{array}{l}\text { Persuasive } \\
\text { marketing } \\
\text { technique }\end{array}$} & \multirow[b]{2}{*}{ Description } & \multirow[b]{2}{*}{ Example } & \multicolumn{3}{|c|}{ Prevalence in ads, $\%^{a}$} \\
\hline & & & $\begin{array}{l}\text { Noncore } \\
\text { food }\end{array}$ & $\begin{array}{l}\text { Core and } \\
\text { misc. foods }\end{array}$ & Total \\
\hline Taste appeal & $\begin{array}{l}\text { Description/depiction of food product } \\
\text { as tasting or smelling good }\end{array}$ & $\begin{array}{l}\text { "Fresh, whole fish fillet - Deliciously } \\
\text { crispy! Spicy green curry sauce..." } \\
\text { (burger ad from a famous fast food } \\
\text { chain) }\end{array}$ & 42.3 & 8.5 & 50.7 \\
\hline Unique/new & $\begin{array}{l}\text { Description/depiction of food product } \\
\text { as "new," "different," "modern," or } \\
\text { "in-fashion," or similar word }{ }^{48}\end{array}$ & $\begin{array}{l}\text { "The New... [ice-cream brand] } \\
\text { Classically Mint. Delicious mint ice cream } \\
\text { with crunchy cookie crumbs... So indulge, } \\
\text { the world can wait." (ice-cream ad) }\end{array}$ & 32.4 & 0.0 & 32.4 \\
\hline Animation & $\begin{array}{l}\text { A computer-generated imaging } \\
\text { technique that builds narrative on } \\
\text { three-dimensional characters. }\end{array}$ & $\begin{array}{l}\text { Animated sequence showing a chocolate } \\
\text { bar and a cookie becoming best friends } \\
\text { and spending time together doing fun } \\
\text { things (chocolate ad) }\end{array}$ & 22.5 & 7.0 & 29.6 \\
\hline Fun appeal & $\begin{array}{l}\text { Both nonverbal displays of fun and } \\
\text { happiness (e.g., smiling or playing) or use } \\
\text { of the words "fun," "happiness," or } \\
\text { "pleasure" } 29\end{array}$ & $\begin{array}{l}\text { Person waiting at bus stop, upon biting } \\
\text { into chocolate bar suddenly has } \\
\text { colorfully dressed characters dancing } \\
\text { around him, twirling him around with } \\
\text { confetti raining down (chocolate ad) }\end{array}$ & 22.5 & 4.2 & 26.8 \\
\hline $\begin{array}{l}\text { Promotional } \\
\text { characters }\end{array}$ & $\begin{array}{l}\text { Includes brand identification characters, } \\
\text { licensed characters, unlicensed } \\
\text { characters, and celebrities or popular } \\
\text { personalities, including sports persons, } \\
\text { health professionals, or scientists }\end{array}$ & $\begin{array}{l}\text { Ad for sweetened biscuits hosted and } \\
\text { narrated by two local Malaysian and } \\
\text { Indonesian celebrities (biscuit ad) }\end{array}$ & 15.5 & 5.6 & 21.1 \\
\hline Price advantages & $\begin{array}{l}\text { Description/depiction of food product } \\
\text { as "economical" or "value for money" } 29\end{array}$ & $\begin{array}{l}\text { Fast food chain advertising their "Bucket } \\
\text { Berbaloi" (or "Value Bucket"), which is } \\
\text { priced "from only RM } 26.90 \text { for } 2-3 \text { pax" } \\
\text { (fried chicken ad) }\end{array}$ & 12.7 & 1.4 & 14.1 \\
\hline $\begin{array}{l}\text { Health and nutrition } \\
\text { benefits }\end{array}$ & $\begin{array}{l}\text { General statement about health } \\
\text { or nutritive benefits of food product } \\
\text { to user }{ }^{48}\end{array}$ & $\begin{array}{l}\text { "Introducing a breakthrough in pediatric } \\
\text { nutrition... Research shows that MFGM } \\
\text { (milk fat globule membrane) together } \\
\text { with DHA (an omega-3 fatty acid) } \\
\text { helps support mental and emotional } \\
\text { development." (formula milk ad) }\end{array}$ & 8.5 & 45.1 & 53.5 \\
\hline Premium offers & $\begin{array}{l}\text { Food advertisement depicts a premium } \\
\text { offer with purchase of the food product, } \\
\text { for example, competition, giveaway } \\
\text { (such as a toy or tickets to a venue } \\
\text { or show), rebate, or voucher }{ }^{48}\end{array}$ & $\begin{array}{l}\text { "Win up to RM50 worth of vouchers..." } \\
\text { (cereal ad) }\end{array}$ & 0.0 & 1.4 & 1.4 \\
\hline
\end{tabular}

aPercentages do not amount to $100 \%$ as many ads apply more than one technique.

also has the potential to maintain children's attention for longer periods as they are now able to choose exactly which videos they want to watch-for as many times as they like. In addition, ads on social media are further tailored to one's personal interests, facilitated by browser cookies that continuously collect information such as visited websites or products viewed on online stores. Such behavioral or personalized marketing (which cannot be done via traditional media) has greater persuasive power, specifies audiences with precision, and has the ability to target the most vulnerable population groups. ${ }^{51}$

Due to the availability of different ad formats (video vs. overlay) within the same platform, this case study was also able to demonstrate that unhealthy foods were being promoted more aggressively to children compared to other foods. Noncore foods were more frequently advertised via video ads, which are more prominent and applied more persuasive marketing techniques per ad (data not shown) than overlay ads. Being video, these ads need to be filmed and edited, with animation often involved, and are thus far more expensive to make and place than the overlay ads (which are usually just text or static images). ${ }^{46,55}$

We also observed in our study that the most frequent persuasive marketing techniques detected among ads promoting noncore foods were taste appeal and the depiction of a food product as being unique, new, or in-fashion. A 
comparable study documenting persuasive marketing techniques used in television ads found similar results with food taste, physical qualities, and novelty reported as the top three most common techniques. ${ }^{21}$ While some countries do restrict the use of premium offers and promotional characters to promote food to children, ${ }^{56}$ promotional appeals such as taste and uniqueness/novelty are not currently subject to regulatory limitations in any country. ${ }^{29}$

Discourse on limiting the extent of unhealthy food marketing to children is usually focused on two main avenuesstatutory regulation and industry (advertisers) self-regulation. In this rapidly changing media environment, however, current legislation and policies with regard to the marketing of unhealthy food to children are not consistent or rigorous, and clearly lag behind children's adoption of online and social media, while self-regulatory codes often have a narrow scope, weak criteria, and limited government oversight. ${ }^{51}$ A possible explanation for slow progress in this area may be that digital media marketing expenditure for food and beverage companies still remains lower in absolute spending compared to television advertising. ${ }^{35}$ Even so, it should be stressed that advertising on new media leverages upon targeted behavioral marketing and is relatively cheap$\mathrm{er}^{57}$ compared to traditional advertising placement. Therefore comparisons of absolute ad expenditures between broadcast and digital channels poorly reflect the relative measures of their actual extent and reach.

Perhaps, a third mechanism should be conceptualized to limit unhealthy food marketing to children in digital media - in the form of resolute restrictions put in place by providers of the service or platform. The YouTube Kids app (Google, Inc., California, USA) sets a real-life precedent for a complete ban of food marketing in a media environment primarily aimed at children. It is a separate entity from the regular YouTube mobile app, and uses filters powered by algorithms to select family-friendly videos from YouTube. It also allows certain parental controls and settings such as setting a timer to limit how much time a child spends on the app. Although sponsored commercials still appear in videos viewed on the app, its creators' decision to explicitly ban any ads related to consumable food and drinks regardless of nutritional content ${ }^{58}$ is commendable.

However, usage of the app amongst children is dependent on their parents' awareness of it, and is limited to mobile devices only (according to a U.K. study, approximately half the surveyed children aged 3-4 (48\%) and a quarter $(25 \%)$ aged 5-7 were solely using the YouTube Kids app). ${ }^{40}$ Children who continue to access videos via desktop or mobile browsers in addition to the regular YouTube app on a handheld device are still exposed to unconstrained food marketing, which warrants further attention on the exposure of unhealthy food marketing on YouTube through other browsing methods.

If children have the right to participate in digital media, their health and privacy should be protected and not economically exploited. ${ }^{51}$ Therefore, in a rights-based approach to addressing the marketing of unhealthy food to children, parents should be supported in upholding these rights by both governments and businesses especially the technology conglomerates behind many of today's social media services. Considering the predominance of unhealthy food marketing in digital media, relevant stakeholders need to work toward establishing a balance between profits and their corporate, ethical, and social responsibilities in relation to food marketing to children.

A limitation inherent to this type of study could be the influence of "cookies" on ads appearing within the sampled videos. However, we mitigated any potential bias by using the "incognito" browser mode during our recording sessions. Thus, the "cookie-free" data collected on ads in our study were assessed to be the minimum extent of noncore food and beverage marketing within child-oriented videos on YouTube. We anticipate the exposure may be even more prevalent in actuality when cookie-facilitated targeted marketing is used by food and beverage advertisers to track children's online habits.

Ads shown on YouTube may also differ by geographical locations as detected by the IP address of the user. As videos were viewed from Malaysia, ads encountered could have been country-specific. Hence, our findings may not necessarily be representative of all regions. In shortlisting the most popular child-centric videos for our sample, we were only able to use global rankings as country-level data on the most popular videos were not freely available. Due to YouTube's minimum sign-up age requirement of 13 years, detailed demographic data for younger users are unlikely to be derived from the operational data collected by the service provider, thereby posing a further challenge in determining children's absolute exposures to food marketing on the platform.

Other recognized challenges include limited access to data and intelligence analytics on marketing on social media (often considered "commercially privileged" information by service providers of social media platforms), and ethical barriers in gaining access to private social media accounts or children's devices. ${ }^{51}$ Future research in this area may be thus limited to observational experiments involving, for example, the emulation of children's browsing habits to account for targeted advertising.

\section{Conclusion}

Our case study analysis of ads encountered in YouTube videos targeted at children revealed that food and beverage ads appeared most frequently (reflecting overall trends in television ads), with more than half of these promoting noncore or unhealthy foods. Unhealthy food ads were to a greater extent delivered via more enticing ad formats compared to ads for other foods. Policies regulating food marketing to children need to be extended to cover online content, and key recommendations for developing these have been described elsewhere. ${ }^{51}$ However given the usually lengthy period it takes for legislation to be drafted, passed, and take effect against a rapidly changing digital 
medial environment, awareness of children's rights and social responsibility on the part of social media service providers will be helpful in limiting the widespread promotion of unhealthy food to children.

\section{Acknowledgment}

The authors wish to thank the Director General of Health, Malaysia for permission to publish this article.

\section{Author Disclosure Statement}

No competing financial interests exist.

\section{References}

1. Lobstein T, Baur L, Uauy R. Obesity in children and young people: A crisis in public health. Obes Rev 2004;5 Suppl 1:4-85.

2. Morgen CS, Sørensen TIA. Obesity: Global trends in the prevalence of overweight and obesity. Nat Rev Endocrinol 2014;10:513-514.

3. Ng M, Fleming $\mathrm{T}$, Robinson $\mathrm{M}$, et al. Global, regional, and national prevalence of overweight and obesity in children and adults during 1980-2013: A systematic analysis for the Global Burden of Disease Study 2013. Lancet 2014;384:766-781.

4. Wang Y, Beydoun MA. The obesity epidemic in the United States-Gender, age, socioeconomic, racial/ethnic, and geographic characteristics: A systematic review and meta-regression analysis. Epidemiol Rev 2007;29:6-28.

5. Must A, Strauss RS. Risks and consequences of childhood and adolescent obesity. Int J Obes Relat Metab Disord 1999; 23:S2-S11.

6. Biro FM, Wien M. Childhood obesity and adult morbidities. Am J Clin Nutr 2010;91:1499-1505.

7. Park MH, Falconer C, Viner RM, Kinra S. The impact of childhood obesity on morbidity and mortality in adulthood: A systematic review. Obes Rev 2012;13:985-1000.

8. Faienza MF, Wang DQH, Frühbeck $G$, et al. The dangerous link between childhood and adulthood predictors of obesity and metabolic syndrome. Intern Emerg Med 2016;11:175-182.

9. Summerbell CD, Waters E, Edmunds LD, et al. Interventions for preventing obesity in children. Cochrane Database Syst Rev 2005;: CD001871.

10. Lake A, Townshend T. Obesogenic environments: Exploring the built and food environments. J R Soc Promot Health 2006;126:262-267.

11. Cairns G, Angus K, Hastings G. The extent, nature and effects of food promotion to children: A review of the evidence. Technical paper prepared for the World Health Organization, 2009.

12. Cairns G, Angus K, Hastings G, Caraher M. Systematic reviews of the evidence on the nature, extent and effects of food marketing to children. A retrospective summary. Appetite 2013;62:209-215.

13. Hawkes C, Lobstein T. Regulating the commercial promotion of food to children: A survey of actions worldwide. Int $J$ Pediatr Obes 2011;6:83-94.

14. Kelly B, Halford JCG, Boyland EJ, et al. Television food advertising to children: A global perspective. Am J Public Health 2010; 100:1730-1736.

15. Kelly B, Hebden L, King L, et al. Children's exposure to food advertising on free-to-air television: An Asia-Pacific perspective. Health Promot Int 2014;31:144-152.
16. Neville L, Thomas M, Bauman A. Food advertising on Australian television: The extent of children's exposure. Health Promot Int 2005;20:105-112.

17. Karupaiah T, Chinna K, Mee LH, et al. What's on Malaysian television?-A survey on food advertising targeting children. Asia Pac J Clin Nutr 2008;17:483-491.

18. Scully P, Macken A, Leddin D, et al. Food and beverage advertising during children's television programming. Ir J Med Sci 2015; 184:207-212.

19. Keller SK, Schulz PJ. Distorted food pyramid in kids programmes: A content analysis of television advertising watched in Switzerland. Eur J Public Health 2011;21:300-305.

20. Boyland EJ, Harrold JA, Kirkham TC, Halford JCG. The extent of food advertising to children on UK television in 2008. Int J Pediatr Obes 2011;6:455-461.

21. Galcheva S V, Iotova VM, Stratev VK. Television food advertising directed towards Bulgarian children. Arch Dis Child 2008; 93:857-861.

22. Ok MA, Ercan A, Kaya FS. A content analysis of food advertising on Turkish television. Health Promot Int 2016;31:801-808.

23. Cauchi D, Reiff S, Knai C, et al. Television food advertising to children in Malta. Health Promot Int 2017;32:419-429.

24. Amini M, Omidvar N, Yeatman H, et al. Content analysis of food advertising in Iranian Children's Television Programs. Int J Prev Med 2014;5:1337-1342.

25. Li D, Wang T, Cheng Y, et al. The extent and nature of television food advertising to children in Xi'an, China. BMC Public Health 2016;16:770.

26. Vilaro MJ, Barnett TE, Watson AM, et al. Weekday and weekend food advertising varies on children' $s$ television in the USA but persuasive techniques and unhealthy items still dominate. Public Health 2016;142:22-30.

27. Mchiza ZJ, Temple NJ, Steyn NP, et al. Content analysis of television food advertisements aimed at adults and children in South Africa. Public Health Nutr 2013;16:2213-2220.

28. Huang L, Mehta K, Wong ML. Television food advertising in Singapore: The nature and extent of childrens exposure. Health Promot Int 2012;27:187-196.

29. Jenkin G, Madhvani N, Signal L, Bowers S. A systematic review of persuasive marketing techniques to promote food to children on television. Obes Rev 2014;15:281-293.

30. Kelly B, Bochynska K, Kornman K, Chapman K. Internet food marketing on popular children's websites and food product websites in Australia. Public Health Nutr 2008;11:1180-1187.

31. Ustjanauskas AE, Harris JL, Schwartz MB. Food and beverage advertising on children's web sites. Pediatr Obes 2014;9:362-372.

32. Vandevijvere S, Sagar K, Kelly BP, Swinburn B. Unhealthy food marketing to New Zealand children and adolescents through the internet. New Zeal Med Assoc 2017;130:32-43.

33. Culp J, Bell RA, Cassady D. Characteristics of food industry web sites and "Advergames" targeting children. J Nutr Educ Behav 2010;42:197-201.

34. Weber K, Story M, Harnack L. Internet food marketing strategies aimed at children and adolescents: A content analysis of food and beverage brand web sites. J Am Diet Assoc 2006;106:1463-1466.

35. Powell LM, Harris JL, Fox T. Food marketing expenditures aimed at youth: Putting the numbers in context. Am J Prev Med 2013;45: 453-461.

36. Mackey TK, Cuomo RE, Liang BA. The rise of digital direct-toconsumer advertising?: Comparison of direct-to-consumer advertising expenditure trends from publicly available data sources and global policy implications. BMC Health Serv Res 2015;15:236. 
37. Elias N, Sulkin I. Youtube viewers in diapers: An exploration of factors associated with amount of toddlers' online viewing. $C y$ berpsychology 2017;11.

38. Ofcom. 2016. Children and parents: Media use and attitudes report. Available at: https://www.ofcom.org.uk/_data/assets/pdf_ file/0034/93976/Children-Parents-Media-Use-Attitudes-Report-2016 .pdf (last accessed November 29, 2017).

39. YouTube. 2017. Press-YouTube. Available at: https://www.youtube .com/yt/about/press (last accessed November 25, 2017).

40. Ofcom. 2017. Children and parents: Media use and attitudes report. Available at: https://www.ofcomorg.uk/_data/assets/pdf_file/0020/ 108182/children-parents-media-use-attitudes-2017.pdf (last accessed April 9, 2018).

41. Holloway D, Green L, Love C. "It"s all about the apps': Parental mediation of pre-schoolers' digital lives. Media Int Aust 2014; $148-156$.

42. Kabali HK, Irigoyen MM, Nunez-Davis R, et al. Exposure and use of mobile media devices by young children. Pediatrics 2015;136: 1044-1050.

43. Radesky JS, Schumacher J, Zuckerman B. Mobile and interactive media use by young children: The good, the bad, and the unknown. Pediatrics 2015;135:1-3.

44. Google. 2017. Chrome Browser-Privacy Policy. Available at: https://www.google.com/chrome/browser/privacy/\#browser-modes (last accessed November 25, 2017).

45. YouTube. 2017. Ads on Youtube-YouTube. Available at: https:// creatoracademy.youtube.com/page/lesson/ad-types (last accessed November 24, 2014).

46. Pedotto L. The complete list of YouTube ad specification. Available at: https://strikesocial.com/blog/youtube-ad-specifications (last accessed April 13, 2018).

47. $\mathrm{Ng} \mathrm{SH}$, Kelly B, Se CH, et al. Obesogenic television food advertising to children in Malaysia: Sociocultural variations. Glob Health Action 2014;7:25169.

48. Hebden L, King L, Kelly B. Art of persuasion: An analysis of techniques used to market foods to children. J Paediatr Child Health 2011;47:776-782.

49. Zuppa JA, Morton H, Mehta KP. Television food advertising: Counterproductive to children's health? A content analysis using the Australian Guide to Health Eating. Nutr Diet 2003;60:78-84.

50. Cavalier S. The World History of Animation. Aurum; 2011, p. 416.
51. World Health Organization. Tackling food marketing to children in a digital world: Trans-disciplinary perspectives. 2016;1-52. Available at: www.euro.who.int/_data/assets/pdf_file/0017/322226/ Tackling-food-marketing-children-digital-world-trans-disciplinaryperspectives-en.pdf (last accessed November 25, 2017).

52. Buzzi M. What are your children watching on YouTube? In: Cipolla-Ficarra F, Veltman K, Verber D, Cipolla-Ficarra M, Kammüller F (ed), Advances in New Technologies, Interactive Interfaces and Communicability ADNTIIC 2011. Berlin, Heidelberg: Springer, 2011, pp. 243-252.

53. Carter OBJ, Patterson LJ, Donovan RJ, et al. Children's understanding of the selling versus persuasive intent of junk food advertising: Implications for regulation. Soc Sci Med 2011;72:962-968.

54. Robinson TN, Borzekowski DLG, Matheson DM, Kraemer HC. Effects of fast food branding on young children's taste preferences. Arch Pediatr Adolesc Med 2007;161:792.

55. Marthinusen L. 2017. How do YouTube ads work, and what will it cost me? Available at: https://www.mo.agency/blog/youtube-adswork-will-cost (last accessed April 12, 2018).

56. Hawkes BC. Marketing food to children: Changes in the global regulatory environment. Geneva, Switzerland, World Health Organization, 2004. Available at http:/www.whqlibdoc.who.int/ publications/2004/9241591579.pdf (last accessed November 25, 2017).

57. Kelly B, Vandevijvere S, Freeman B, Jenkin G. New media but same old tricks: Food marketing to children in the digital age. Curr Obes Rep 2015;4:37-45.

58. Google. 2017. Advertising on YouTube Kids-YouTube Help. Available at: https://support.google.com/youtube/answer/6168681 (last accessed November 25, 2017).

Address correspondence to: LeeAnn Tan, $M B$ BCh BAO Institute for Public Health Ministry of Health Malaysia Jalan Bangsar 50590 Kuala Lumpur Malaysia

E-mail: leeann@moh.gov.my 


\begin{tabular}{|c|c|c|c|c|c|}
\hline Rank & Channel name & $\begin{array}{c}\text { Total } \\
\text { subscribers }\end{array}$ & $\begin{array}{l}\text { Total video } \\
\text { views }^{\mathbf{a}}\end{array}$ & $\begin{array}{l}\text { Summary of } \\
\text { content }\end{array}$ & $\begin{array}{l}\text { Links to list of top } 10 \text { videos, } \\
\text { sorted by views }\end{array}$ \\
\hline I & Ryan ToysReview & $9,101,532$ & $15,706,699,819$ & $\begin{array}{l}\text { Toy reviews, toy } \\
\text { unboxing videos }\end{array}$ & $\begin{array}{l}\text { https://www.youtube.com/channel/ } \\
\text { UChGJGhZ9SOOHvBBOY4DOO_w/ } \\
\text { videos?flow=list\&view=0\&sort=p }\end{array}$ \\
\hline 2 & LittleBabyBum $^{\circledR}$ & $12,743,616$ & $14,332,110,973$ & $\begin{array}{l}\text { Nursery rhymes, } \\
\text { children's songs }\end{array}$ & $\begin{array}{l}\text { https://www.youtube.com/user/LittleBabyBum/ } \\
\text { videos?sort=p\&view=0\&flow=list\&live_view=500 }\end{array}$ \\
\hline 3 & $\begin{array}{l}\text { FunToys Collector } \\
\text { Disney Toys Review }\end{array}$ & $9,456,628$ & $13,276,059,099$ & $\begin{array}{l}\text { Toy reviews, toy } \\
\text { unboxing videos }\end{array}$ & $\begin{array}{l}\text { https://www.youtube.com/user/DisneyCollector } \\
\text { BR/videos?sort=p\&view=0\&flow=list }\end{array}$ \\
\hline 4 & $\begin{array}{l}\text { Маша и Медведь } \\
\text { (Masha and the Bear) }\end{array}$ & $11,235,425$ & $12,862,038,609$ & Animated series & $\begin{array}{l}\text { https://www.youtube.com/user/Masha } \\
\text { MedvedTV/videos?view=0\&flow=list\&sort=p }\end{array}$ \\
\hline 5 & $\begin{array}{l}\text { El Reino Infantil (The } \\
\text { Children's Kingdom) }\end{array}$ & $8,864,823$ & $10,749,243,080$ & Children's songs & $\begin{array}{l}\text { https://www.youtube.com/user/ReinoMaria } \\
\text { ElenaWalsh/videos?flow=list\&view=0\&sort=p }\end{array}$ \\
\hline 6 & Family Fun Pack & $5,7|4,34|$ & $10,513,188,018$ & Family vlogs & $\begin{array}{l}\text { https://www.youtube.com/user/familyfunpack/ } \\
\text { videos?sort=p\&flow=list\&view=0 }\end{array}$ \\
\hline 7 & $\begin{array}{l}\text { ChuChu TV Nursery } \\
\text { Rhymes \& Kids Songs }\end{array}$ & $11,923,242$ & $10,474,220,335$ & $\begin{array}{l}\text { Nursery rhymes, } \\
\text { children's songs }\end{array}$ & $\begin{array}{l}\text { https://www.youtube.com/user/TheChuChuTV/ } \\
\text { videos?sort=p\&view=0\&flow=list }\end{array}$ \\
\hline 8 & Baby Big Mouth & $6,520,402$ & $8,617,274,138$ & $\begin{array}{l}\text { Surprise eggs, } \\
\text { educational videos }\end{array}$ & $\begin{array}{l}\text { https://www.youtube.com/user/ltsBabyBigMouth/ } \\
\text { videos?sort=p\&flow=list\&view=0 }\end{array}$ \\
\hline 9 & $\begin{array}{l}\text { Blu Toys Club } \\
\text { Surprise }\end{array}$ & $5,681,092$ & $7,847,702,626$ & $\begin{array}{l}\text { Surprise eggs and } \\
\text { other toys }\end{array}$ & $\begin{array}{l}\text { https://www.youtube.com/user/Blucollection/ } \\
\text { videos?sort=p\&view=0\&flow=list }\end{array}$ \\
\hline 10 & $\begin{array}{l}\text { DCToys Sandaroo } \\
\text { Kids }\end{array}$ & $5,528,709$ & $7,327,029,79 \mid$ & $\begin{array}{l}\text { Toy reviews, toy } \\
\text { unboxing videos }\end{array}$ & $\begin{array}{l}\text { https://www.youtube.com/user/DisneyCarToys/ } \\
\text { videos?sort=p\&flow=list\&view=0 }\end{array}$ \\
\hline II & $\begin{array}{l}\text { [토이푸딩] } \\
\text { ToyPudding TV }\end{array}$ & $9,182,365$ & $7,323,752,103$ & $\begin{array}{l}\text { Surprise eggs and } \\
\text { other toys }\end{array}$ & $\begin{array}{l}\text { https://www.youtube.com/user/toypudding/ } \\
\text { videos?sort=p\&flow=list\&view=0 }\end{array}$ \\
\hline 12 & $\begin{array}{l}\text { Super Simple } \\
\text { Songs-Kids Songs }\end{array}$ & $7,077,954$ & $7,27 \mid, 403,947$ & Children's songs & $\begin{array}{l}\text { https://www.youtube.com/user/SuperSimple } \\
\text { Songs/videos?sort=p\&flow=list\&view }=0\end{array}$ \\
\hline 13 & DCTC Toy Channel & $8,145,406$ & $7,081,696,749$ & $\begin{array}{l}\text { Toy reviews, toy } \\
\text { unboxing videos }\end{array}$ & $\begin{array}{l}\text { https://www.youtube.com/user/MaterCarClub/ } \\
\text { videos?view=0\&flow=list\&sort=p }\end{array}$ \\
\hline 14 & Toy Freaks & $7,925,209$ & $6,735,039,517$ & Family vlogs & $\begin{array}{l}\text { https://www.youtube.com/user/3uptheyingyang/ } \\
\text { videos?flow=list\&sort=p\&view=0 }\end{array}$ \\
\hline 15 & $\begin{array}{l}\text { Toys and Funny Kids } \\
\text { Surprise Eggs }\end{array}$ & $7,868,336$ & $6,491,017,480$ & Surprise eggs & $\begin{array}{l}\text { https://www.youtube.com/user/toysand } \\
\text { funnykids/videos?sort=p\&view=0\&flow=list }\end{array}$ \\
\hline 16 & Galinha Pintadinha & $8,100,926$ & $6,425,823,195$ & Children's songs & $\begin{array}{l}\text { https://www.youtube.com/user/juptube/ } \\
\text { videos?sort=p\&flow=list\&view=0 }\end{array}$ \\
\hline 17 & $\begin{array}{l}\text { Webs \& Tiaras- } \\
\text { Toy Monster } \\
\text { Compilations }\end{array}$ & $6,772,315$ & $6,281,291,402$ & Skit videos & $\begin{array}{l}\text { https://www.youtube.com/channel/ } \\
\text { UC0gNKhFMg-bKyNNZ_MB3D9Q/ } \\
\text { videos?flow=list\&sort=p\&view=0 }\end{array}$ \\
\hline 18 & Лунтик (Luntik) & $2,373,790$ & $5,843,660,798$ & Animated series & $\begin{array}{l}\text { https://www.youtube.com/user/luntik/ } \\
\text { videos?flow=list\&view=0\&sort=p }\end{array}$ \\
\hline 19 & ToyScouter & $8,561,187$ & $5,682,006,994$ & Toy reviews & $\begin{array}{l}\text { https://www.youtube.com/user/toyscouter/ } \\
\text { videos?sort=p\&view=0\&flow=list }\end{array}$ \\
\hline 20 & CVS 3D Rhymes & $7,052,324$ & $5,620,537,315$ & $\begin{array}{l}\text { Nursery rhymes, } \\
\text { children's songs }\end{array}$ & $\begin{array}{l}\text { https://www.youtube.com/user/CyberVillage } \\
\text { Solution/videos?sort=p\&view=0\&flow=list }\end{array}$ \\
\hline 21 & Mister Max & $5,053,436$ & $5,459,876,998$ & Vlogs, toy reviews & $\begin{array}{l}\text { https://www.youtube.com/channel/UC_8PAD0 } \\
\text { Qmi6_gpe77SIAtgg/videos?flow=list\& } \\
\text { view=0\&sort=p }\end{array}$ \\
\hline
\end{tabular}




\begin{tabular}{|c|c|c|c|c|c|}
\hline Rank & Channel name & $\begin{array}{l}\text { Total } \\
\text { subscribers }\end{array}$ & $\begin{array}{l}\text { Total video } \\
\text { views }^{\mathrm{a}}\end{array}$ & $\begin{array}{l}\text { Summary of } \\
\text { content }\end{array}$ & $\begin{array}{l}\text { Links to list of top I } 0 \text { videos, } \\
\text { sorted by views }\end{array}$ \\
\hline 22 & LEGO & $3,397,763$ & $5,423,117,724$ & Toys showcase & $\begin{array}{l}\text { https://www.youtube.com/user/LEGO/ } \\
\text { videos?sort=p\&view=0\&flow=list }\end{array}$ \\
\hline 23 & Mother Goose Club & $4,507,439$ & $5,404,368,023$ & Children's songs & $\begin{array}{l}\text { https://www.youtube.com/user/ } \\
\text { MotherGooseClub/ } \\
\text { videos?view=0\&sort=p\&flow=list }\end{array}$ \\
\hline 24 & Miss Katy & $4,815,998$ & $5,320,356,429$ & Vlogs, toy reviews & $\begin{array}{l}\text { https://www.youtube.com/channel/ } \\
\text { UCcartHVtvAUzfajflyeT_Gg/ } \\
\text { videos?sort=p\&flow=list\&view=0 }\end{array}$ \\
\hline 25 & DisneyJuniorUK & $3,449,481$ & $4,398,337,349$ & Animated videos & $\begin{array}{l}\text { https://www.youtube.com/user/DisneyJuniorUK/ } \\
\text { videos?sort=p\&flow=list\&view=0 }\end{array}$ \\
\hline
\end{tabular}

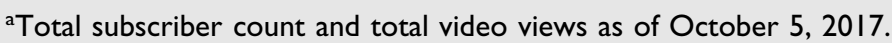

https://socialblade.com/youtube/top/tag/kids/videoviews 


\section{Appendix 2. Food and Beverage Categories}

\section{Food category}

Core and healthy food categories

Breads, rice, and rice products without added fat, sugar, or salt

Low sugar and high fiber breakfast cereals ( $<20 \mathrm{~g}$ sugar $/ 100 \mathrm{~g}$ and $>5 \mathrm{~g}$ dietary fiber/ $/ 00 \mathrm{~g}$ )

Fruits and fruit products without added fats, sugars, or salt

Vegetables and vegetable products without added fats, sugars, or salt

Plain milks and yoghurts, cheese, and alternatives

Meat and meat alternatives

Oils high in mono- or polyunsaturated fats, and low fat sauces $(<10 \mathrm{~g} \mathrm{fat} / \mathrm{l} 00 \mathrm{~g})$

Low fat/salt meals: meals ( $\leq 6 \mathrm{~g}$ saturated fat $/$ serve, $\leq 900 \mathrm{mg}$ sodium $/$ serve), soups $(<2 \mathrm{~g} \mathrm{fat} / 100 \mathrm{~g}$, exclude dehydrated), sandwiches, mixed salads

Healthy Snacks: $<600 \mathrm{~kJ} / \mathrm{serve},<3 \mathrm{~g}$ saturated fat/serve and $<200 \mathrm{mg}$ sodium/serve

Baby foods (exclude milk formulae)

Bottled water (include unflavored mineral and soda waters)

Noncore and unhealthy food categories

High sugar and/or low fiber breakfast cereals $(>20 \mathrm{~g}$ sugars $/ 100 \mathrm{~g}$ or $<5 \mathrm{~g}$ dietary fiber/l00 $\mathrm{g}$ )

Flavored/fried instant rice and noodle products

Sweet breads/cakes/muffins/buns, sweet glutinous rice balls/cakes, high fat savory biscuits, pies, and pastries, sweet sticky rice/rice pudding

Meat and meat alternatives processed or preserved in salt

Sweet snack foods-jelly, sugar-coated dried fruits or nuts, nut/seed-based bars and slices, sweet rice bars, and tinned fruit in syrup

Savory snack foods (added salt or fat)—chips, dried spicy peas, fruit chips, savory crisps, extruded snacks, popcorn (exclude plain), salted or coated nuts, and other fried snacks

Fruit juice/drinks (<98\% fruit)

Flavored or dairy products with added sugar and alternatives

Ice cream, iced confection, and desserts

Chocolate and candy

Fast food (not only healthier options advertised)

High fat/salt meals_frozen or packaged meals ( $>6 \mathrm{~g}$ saturated fat $/ \mathrm{serve},>900 \mathrm{mg}$ sodium $/ \mathrm{serve}$ )

Other high fat/salt products-high fat savory sauces $(>10 \mathrm{~g} f a t / 100 \mathrm{~g})$, soups $(>2 \mathrm{~g}$ fat $/ 100 \mathrm{~g}$; all dehydrated)

Sugar sweetened drinks

Alcohol

\section{Miscellaneous}

Recipe additions (including soup cubes, oils, dried herbs, and seasonings)

Vitamin/mineral or other dietary supplements

Tea and coffee

Baby and toddler milk formulae

Fast food (only healthier options advertised)

Fast food (not only healthier options advertised)

Fast-food restaurant (no foods or beverages advertised)

Local restaurant

Supermarkets (only core and healthy foods advertised)

Supermarkets (not only core and healthy foods advertised)

Supermarkets (no foods or drinks advertised) 